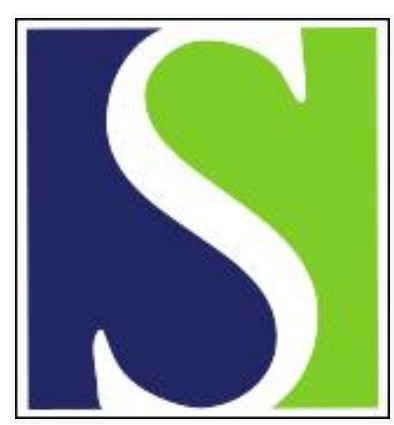

Scand J Work Environ Health 1990;16(6):381-393

https://doi.org/10.5271/sjweh.1767

Issue date: 01 Dec 1990

Epidemiologic evidence on the relationship between formaldehyde exposure and cancer.

by Blair A, Saracci R, Stewart PA, Hayes RB, Shy C

Affiliation: National Cancer Institute, Occupational Studies Section, Rockville, MD 20892.

This article in PubMed: www.ncbi.nlm.nih.gov/pubmed/2284588

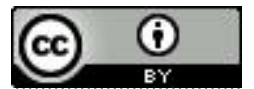




\title{
Epidemiologic evidence on the relationship between formaldehyde exposure and cancer
}

\author{
by Aaron Blair, PhD, ${ }^{1}$ Rodolfo Saracci, MD, ${ }^{2}$ Patricia A Stewart, MS, ${ }^{1}$ \\ Richard B Hayes, DDS, PhD, ${ }^{1}$ Carl Shy, $\mathrm{MD}^{3}$
}

\begin{abstract}
BLAIR A, SARACCI R, STEWART PA, HAYES RB, SHY C. Epidemiologic evidence on the relationship between formaldehyde exposure and cancer. Scand J Work Environ Health 1990;16:381-93. Over 30 epidemiologic studies have evaluated cancer risks associated with formaldehyde exposure. Excesses were reported for several sites, leukemia and cancers of the nasal cavities, nasopharynx, lung, and brain generating the greatest interest. The excesses of leukemia and brain and colon cancer found among professionals may not be related to formaldehyde exposure, since similar excesses were not observed among industrial workers. Inconsistencies among and within studies impede assigning formaldehyde a convincing causal role for the excesses of lung cancer found among industrial workers. A causal role for formaldehyde is the most probable for cancers of the nasopharynx and, to a less extent, the nasal cavities. Evidence of exposure-response relationships, the fact that direct contact with formaldehyde may occur at these upper respiratory sites, and the consistency of these findings with experimental studies make this assumption highly probable.
\end{abstract}

Key terms: lung, meta-analysis, nasal, nasopharynx, review.

Animal bioassays $(1,2)$ indicate that formaldehyde causes nasal tumors in rats. The widespread use of formaldehyde in industry and in commercial products has heightened public health concerns regarding this chemical. In the United States, the National Occupational Hazards Survey (3) of the National Institute for Occupational Safety and Health indicates that 1.6 million workers may be exposed to formaldehyde during the manufacture of formaldehyde resins, textiles, garments, particle board and plywood, insulating materials, dinnerware, and paper and in health-related professions. In addition, off-gassing of formaldehyde from certain consumer products may lead to exposure of large numbers of the general public.

The results of animal experiments led to epidemiologic studies on a variety of formaldehyde-exposed populations. Previous reviews of these studies have primarily focused on assessing the weight of evidence concerning formaldehyde as a human carcinogen without a detailed presentation of the study results. In one such review the International Agency for Research on Cancer (IARC) concluded that there is sufficient evidence for the carcinogenicity of formaldehyde in

1 National Cancer Institute, Rockville, Maryland, United States.

2 International Agency for Research on Cancer, Lyon, France.

3 University of North Carolina, Chapel Hill, North Carolina, United States.

Reprint requests to: Dr A Blair, National Cancer Institute, Occupational Studies Section, Executive Plaza North, Room 418, Rockville, MD 20892, USA. animals, but limited evidence for humans (4). Another group concluded that the evidence for the carcinogenicity of formaldehyde in humans was less persuasive than did IARC (5).

In our review of the epidemiologic literature we have summarized results on a site-by-site basis and have focused on potential exposures to formaldehyde and other exposures that the study populations may have experienced to evaluate the strength of the evidence regarding formaldehyde and human cancer.

\section{Study designs}

Over 30 reports from epidemiologic studies on formaldehyde have been published (table 1). These reports have focused on professional groups such as funeral directors and embalmers, anatomists, pathologists, and workers in formaldehyde facilities producing formaldehyde, resins, plastic molding, decorative laminates, plywood, particle board, and apparel. These studies, as well as relevant broad surveys of cancer risk by occupation in the United States, Canada, and Sweden, are included in this review. The studies have been conducted in eight countries (United States, Canada, Great Britain, Denmark, The Netherlands, Finland, Sweden, and Italy) and have employed standardized mortality ratio (SMR), proportionate mortality ratio (PMR), standardized incidence ratio (SIR), and case-referent designs. The total number of cancer cases with potential exposure to formaldehyde in these studies is now large enough to provide considerable statistical power for evaluating the carcinogenicity of formaldehyde in humans for all but rare sites. 
Table 1. Description of the epidemiologic studies on formaldehyde. (PMR $=$ proportionate mortality ratio, $\mathrm{SIR}=\mathrm{standardized}$ incidence ratio, SMR = standardized mortality ratio)

\begin{tabular}{|c|c|c|c|c|c|c|c|c|}
\hline Author & $\begin{array}{l}\text { Study } \\
\text { design }\end{array}$ & $\begin{array}{l}\text { Population } \\
\text { studied }\end{array}$ & $\begin{array}{l}\text { Time } \\
\text { period }\end{array}$ & $\begin{array}{l}\text { Exposure } \\
\text { evaluation }\end{array}$ & $\begin{array}{l}\text { Diseases } \\
\text { reported }\end{array}$ & $\begin{array}{l}\text { Number } \\
\text { of } \\
\text { subjects }\end{array}$ & $\begin{array}{l}\text { Control } \\
\text { of } \\
\text { smoking }\end{array}$ & $\begin{array}{l}\text { Comparison } \\
\text { population }\end{array}$ \\
\hline \multicolumn{9}{|c|}{ Professional and nonoccupational exposures } \\
\hline Petersen \& Milham (6) & PMR & Funeral directors & $1959-1961$ & None & All & & No & California \\
\hline Jensen \& Andersen (7) & $\begin{array}{l}\text { Case- } \\
\text { referent }\end{array}$ & Physicians & $1943-1976$ & Specialty & Lung cancer & $\begin{array}{l}84 \text { cases, } \\
252 \text { referents }\end{array}$ & No & Other cancers \\
\hline Friedman \& Ury (8) & SIR & Pharmacy users & $1969-1978$ & None & $\begin{array}{l}\text { Lung } \\
\text { All cancer }\end{array}$ & 557 & No & $\begin{array}{l}\text { All pharmacy } \\
\text { users }\end{array}$ \\
\hline Milham (9) & PMR & Funeral directors & $1959-1979$ & None & All & 333 & No & Washington \\
\hline Walrath \& Fraumeni (48) & PMR & $\begin{array}{l}\text { Funeral directors, } \\
\text { embalmers }\end{array}$ & $1925-1980$ & $\begin{array}{l}\text { Type of } \\
\text { license }\end{array}$ & All & 1132 & No & United States \\
\hline Harrington \& Shannon (65) & SMR & Pathologists & $1955-1973$ & None & $\begin{array}{l}13 \text { selected } \\
\text { causes }\end{array}$ & 2079 & No & United Kingdom \\
\hline Harrington \& Oakes (64) & SMR & Pathologists & $1974-1980$ & None & $\begin{array}{l}13 \text { selected } \\
\text { causes }\end{array}$ & 2307 & No & United Kingdom \\
\hline Levine et al (47) & SMR & Undertakers & $1928-1977$ & Latency & All & 1477 & No & Ontario \\
\hline Walrath \& Fraumeni (10) & PMR & Embalmers & $1925-1980$ & Duration & All & 1007 & No & United States \\
\hline Gallagher et al (11) & PMR & Funeral directors & $1950-1978$ & None & All & & No & British Columbia \\
\hline Logue et al (12) & SMR & Pathologists & $1962-1977$ & None & Selected & 5585 & No & \\
\hline Stroup et al (49) & SMR & Anatomists & $1888-1979$ & $\begin{array}{l}\text { Specialty, } \\
\text { duration }\end{array}$ & All & 2317 & No & United States \\
\hline Walrath et al (67) & SMR & $\begin{array}{l}\text { Funeral directors, } \\
\text { embalmers }\end{array}$ & $1954-1970$ & None & All & 408 & No & Other veterans \\
\hline Hayes et al (63) & PMR & Funeral directors & $1975-1985$ & None & All & 4046 & No & United States \\
\hline \multicolumn{9}{|l|}{ Industrial workers } \\
\hline Fayerweather et al (40) & $\begin{array}{l}\text { Case- } \\
\text { referent }\end{array}$ & Chemical workers & $1957-1979$ & $\begin{array}{l}\text { Level, } \\
\text { duration }\end{array}$ & All cancer & $\begin{array}{l}481 \text { cases } \\
481 \text { referents }\end{array}$ & Yes & $\begin{array}{l}\text { Other } \\
\text { workers }\end{array}$ \\
\hline Marsh (35) & PMR & Chemical workers & $1950-1976$ & Duration & 32 causes & 603 & No & United States \\
\hline Wong (36) & SMR & Chemical workers & $1940-1977$ & Duration & 23 causes & 2026 & No & United States \\
\hline Liebling et al (37) & PMR & Chemical workers & $1976-1980$ & None & 9 causes & 24 & No & United States \\
\hline Stayner et al (33) & PMR & Garment workers & $1959-1980$ & $\begin{array}{l}\text { Duration, } \\
\text { latency }\end{array}$ & All & 256 & No & United States \\
\hline Acheson et al $(23,68)$ & SMR & Chemical workers & $1937-1981$ & $\begin{array}{l}\text { Level, } \\
\text { duration }\end{array}$ & 13 causes & 7680 & No & $\begin{array}{l}\text { United Kingdom, } \\
\text { local }\end{array}$ \\
\hline Coggon et al (41) & $\begin{array}{l}\text { Case- } \\
\text { referent }\end{array}$ & British deaths & $1975-1979$ & Level & $\begin{array}{l}\text { Lung, } \\
\text { bladder }\end{array}$ & $\begin{array}{l}889 \text { cases } \\
1758 \text { referents }\end{array}$ & No & Other deaths \\
\hline Olsen et al (44) & $\begin{array}{l}\text { Case- } \\
\text { referent }\end{array}$ & $\begin{array}{l}\text { Danish Cancer } \\
\text { Registry }\end{array}$ & $1970-1982$ & Duration & $\begin{array}{l}\text { Nasal, } \\
\text { naso- } \\
\text { pharynx }\end{array}$ & $\begin{array}{l}839 \text { cases } \\
2465 \text { referents }\end{array}$ & No & Other cancers \\
\hline Malker \& Weiner (13) & SIR & $\begin{array}{l}\text { Swedish Cancer- } \\
\text { Environment } \\
\text { Registry }\end{array}$ & $1961-1979$ & None & 6 cancers & 67378 & No & Sweden \\
\hline Partanen et al (31) & $\begin{array}{l}\text { Nested } \\
\text { case- } \\
\text { referent }\end{array}$ & $\begin{array}{l}\text { Finnish wood- } \\
\text { workers }\end{array}$ & $1957-1980$ & $\begin{array}{l}\text { Level, } \\
\text { duration }\end{array}$ & $\begin{array}{l}\text { Respiratory } \\
\text { cancer }\end{array}$ & $\begin{array}{l}60 \text { cases } \\
171 \text { referents }\end{array}$ & Yes & Other workers \\
\hline Bertazzi et al $(30,50)$ & SMR & Resin workers & $1959-1986$ & Duration & 14 causes & 1332 & No & Italy \\
\hline Blair et al $(24-28)$ & SMR & 10 plants & $1934-1980$ & $\begin{array}{l}\text { Level, } \\
\text { duration }\end{array}$ & All & 26561 & No & $\begin{array}{l}\text { United States, } \\
\text { unexposed }\end{array}$ \\
\hline Bond et al (43) & $\begin{array}{l}\text { Nested } \\
\text { case- } \\
\text { referent }\end{array}$ & Chemical workers & $1940-1980$ & Latency & Lung & $\begin{array}{l}308 \text { cases } \\
588 \text { referents }\end{array}$ & Yes & Other workers \\
\hline Hayes et al (42) & $\begin{array}{l}\text { Case- } \\
\text { referent }\end{array}$ & $\begin{array}{l}\text { The Netherland's } \\
\text { hospitals }\end{array}$ & $1978-1981$ & Level & $\begin{array}{l}\text { Nasal } \\
\text { cancer }\end{array}$ & $\begin{array}{c}91 \text { cases } \\
195 \text { referents }\end{array}$ & Yes & $\begin{array}{l}\text { Population } \\
\text { referents }\end{array}$ \\
\hline Vaughan et al $(45,62)$ & $\begin{array}{l}\text { Case- } \\
\text { referent }\end{array}$ & $\begin{array}{l}\text { Washington } \\
\text { Tumor Registry }\end{array}$ & $1979-1983$ & $\begin{array}{l}\text { Level, } \\
\text { duration }\end{array}$ & $\begin{array}{l}\text { Nasal, } \\
\text { pharynx }\end{array}$ & $\begin{array}{l}285 \text { cases, } \\
552 \text { referents }\end{array}$ & Yes & $\begin{array}{l}\text { Population } \\
\text { referents }\end{array}$ \\
\hline Roush et al (59) & $\begin{array}{l}\text { Case- } \\
\text { referent }\end{array}$ & $\begin{array}{l}\text { Connecticut } \\
\text { Tumor Registry }\end{array}$ & $1935-1975$ & $\begin{array}{l}\text { Probability } \\
\text { of expo- } \\
\text { sure }\end{array}$ & $\begin{array}{l}\text { Nasal, } \\
\text { nasopharynx }\end{array}$ & $\begin{array}{l}371 \text { cases, } \\
605 \text { referents }\end{array}$ & No & Other deaths \\
\hline Stayner et al (34) & SMR & Garment workers & $1959-1982$ & Duration & All & 11030 & No & United States \\
\hline Gerin et al (39) & $\begin{array}{l}\text { Case- } \\
\text { referent }\end{array}$ & Montreal & $1979-1985$ & $\begin{array}{l}\text { Level, } \\
\text { duration }\end{array}$ & 19 cancers & 4259 & Yes & $\begin{array}{l}\text { Population and } \\
\text { other cancer }\end{array}$ \\
\hline
\end{tabular}

\section{Exposure information}

Formaldehyde is ubiquitous in the environment. For the assessment of cancer risks associated with formaldehyde exposure, it is of paramount importance that the level of exposure of study subjects be determined.
In epidemiologic studies of formaldehyde exposure and cancer risk various approaches to exposure assessment have been taken, largely dictated by the constraints of the study design. Mortality surveys, such as of professional groups, have relied upon qualitative assessment 
of exposure based upon job title or similar designations. Mortality studies of individual industrial facilities have generally provided more-detailed exposure estimates based on industrial exposure measurements and ancillary information. Case-referent studies composed of persons from a variety of occupations have generally relied on indirect exposure assessment based on knowledge of work practices and exposures in formaldehyde-related jobs.

\section{Study groups}

\section{Professionals}

Embalmers may come in contact with a variety of chemicals, including formaldehyde, phenol, dyes and stains, glutaraldehyde, glycol, glycerol, xylene, alcohols, and particulates, and also with biologic material and gamma radiation (14). Levels of $<2 \mathrm{ppm}$ for solvents (ie, isopropyl alcohol, 1,1,1-trichloroethane, isopentane, and trichloroethylene) and of $1.8 \mathrm{mg} / \mathrm{m}^{3}$ for total dust, and $1.3 \mathrm{mg} / \mathrm{m}^{3}$ for respirable dust measured from hardening compounds have also been reported (15). Published reports on exposure in this profession primarily discuss exposure to formaldehyde. Mean time-weighted average (TWA) values ranging from 0.30 to $1.30 \mathrm{ppm}$ have been reported for formaldehyde during the embalming procedure (15-17), but a recent evaluation by three of the authors (PAS, $\mathrm{RBH}, \mathrm{AB})$ found somewhat higher TWA values $(0.8$ to $2.9 \mathrm{ppm}$ ), with instantaneous peaks of formaldehyde or other aldehydes of up to $20 \mathrm{ppm}$. On the assumption that an embalming takes about $3 \mathrm{~h}$ and that only one embalming occurs per day, the 8-h TWA values in all of these cases would be about $60 \%$ lower. Thus TWA values during embalming operations appear to be similar to those found in industry, but such high peak concentrations have not been reported in industrial facilities.

Chemicals used in anatomy laboratories may be similar to those used in funeral homes, but anatomists appear to have a greater range of exposure to formaldehyde, the TWA values ranging from 0.02 to 5.87 $(18-21)$. Although peak levels in anatomy laboratories have not been reported, they may be similar to those generated during embalming. In studies of cancer risk among professional workers (ie, anatomists, pathologists, and funeral professionals), assessment of exposure to formaldehyde was largely qualitative, being inferred from job titles identified from state licensing records and from membership lists of professional societies with no specific estimates of exposure for study subjects.

\section{Industrial workers}

In contrast to the studies of cancer risk among professional groups, epidemiologic studies of industrial workers (table 2) have generally included quantitative estimakes of the level of exposure to formaldehyde. Estimated levels in these investigations were similar and resembled measurements reported in other settings (22). The six manufacturing facilities in the study by Acheson et al (23) produced formaldehyde, formaldehyde resins, formaldehyde adhesives, paraform, and alcoforms. Exposure to formaldehyde was estimated for each job and assigned to exposure categories of $<0.1,0.1-5,0.6-2.0$, and $>2.0 \mathrm{ppm}$. Monitoring

Table 2. Exposure levels and potential chemical confounders in studies of industrial workers.

\begin{tabular}{|c|c|c|c|c|c|}
\hline Author & $\begin{array}{l}\text { Type of } \\
\text { operation }\end{array}$ & $\begin{array}{l}\text { Formaldehyde } \\
\text { exposures } \\
(\mathrm{ppm})\end{array}$ & $\begin{array}{l}\text { Percentage of } \\
\text { cohort with } \\
\text { high exposure }\end{array}$ & Other chemicals & Comments \\
\hline Stayner et al (33) & $\begin{array}{l}2 \text { garment manufac- } \\
\text { turing plants }\end{array}$ & Current $=0.1-1.0$ & $\cdots$ & None & $\begin{array}{l}\text { Exposures believed } \\
\text { higher in past }\end{array}$ \\
\hline Acheson et al (23) & $\begin{array}{l}5 \text { formaldehyde, resin, } \\
\text { adhesive, paraform, } \\
\text { and alcoforms plants }\end{array}$ & $<0.1->2.0$ & $35 \%>2.0 \mathrm{ppm}$ & Asbestos & Dust in all plants \\
\hline $\begin{array}{l}\text { Blair et al } \\
(24-27)\end{array}$ & $\begin{array}{l}10 \text { formaldehyde, res- } \\
\text { in, molding, photo- } \\
\text { graphic film, plywood } \\
\text { plants }\end{array}$ & $\begin{array}{l}<0.1->2.0 \\
\text { peaks }>4.0\end{array}$ & $3 \%>2.0 \mathrm{ppm}$ & $\begin{array}{l}\text { Alcohol, ureas, anti- } \\
\text { oxidants, plasticiz- } \\
\text { ers, dyes, asbestos, } \\
\text { wood dust, phenol, } \\
\text { stearates, amides, } \\
\text { and others }\end{array}$ & Dust in many plants \\
\hline Stayner et al (34) & $\begin{array}{l}3 \text { garment manufac- } \\
\text { turing plants }\end{array}$ & $\begin{array}{l}\text { Current geometric } \\
\text { mean }=0.14-0.17 \text {, } \\
\text { no peaks mea- } \\
\text { sured }\end{array}$ & . & None & Higher in past \\
\hline $\begin{array}{l}\text { Partanen et al (31) } \\
\text { and Kauppinen \& } \\
\text { Niemelä (32) }\end{array}$ & $\begin{array}{l}19 \text { particleboard, ply- } \\
\text { wood, glue, sawmill } \\
\text { plants }\end{array}$ & . & $\begin{array}{l}9 \%>1.5 \text { (aver- } \\
\text { age exposure) }\end{array}$ & $\begin{array}{l}\text { Wood dust, glues, } \\
\text { pesticides, phenol, } \\
\text { terpenes, solvents, } \\
\text { exhaust gases, } \\
\text { molds }\end{array}$ & \\
\hline Bertazzi et al $(30)$ & 1 resin plant & $\begin{array}{l}1974-1979 \text { mean } \\
\text { levels }=0.2-3.8\end{array}$ & . & $\begin{array}{l}\text { Urea, melamine, sty- } \\
\text { rene, expoxy resins, } \\
\text { solvents, epichlor- } \\
\text { hydrin }\end{array}$ & Past levels higher \\
\hline
\end{tabular}


data available since 1970 and interviews with management and long-term employees about process changes and controls were used to estimate the exposure levels. Twenty-five percent of the subjects were unexposed. Among those holding jobs where exposure occurred, $35 \%$ had their highest exposed job in the low-exposure category, $14 \%$ had their highest exposed job in the moderate category, and $51 \%$ had their highest exposed job in the high category ( $>2.0 \mathrm{ppm})$. The authors specifically mentioned the presence of only one other substance, asbestos, but we assume that many of the chemicals identified in the formaldehyde and resin plants studied by Blair et al (24-27), such as wood dust, phenol, melamine, and urea, may have also been present in the formaldehyde and resin plants in this study.

Blair et al (24-29) studied 10 plants producing a variety of products, including formaldehyde, formaldehyde resins and molding compounds, decorative laminates, photographic film, and plywood. The estimates of formaldehyde levels for each unique combination of job, department, plant, and calendar-year combination were based on the results of monitoring conducted by the investigators (about 2000 full-shift personal samples) (27), company monitoring results (over 4500 results dating back to the 1960 s for some plants), plant visits, job descriptions, and interviews with management and long-term employees regarding changes in the process, controls, work practices, and sensory perceptions (26). With the use of these estimates jobs were assigned to categories of trace, $\leq 0.1$, $0.1-<0.5,0.5-1.9$, and $\geq 2.0 \mathrm{ppm}$. In addition, for each job, estimates were made for the level and frequency of peak exposures, the potential for exposure to formaldehyde in liquid or particulate form, the possibility of other chemical exposures, and the industrial hygienists' confidence in the estimates. Eight percent of the cohort never held exposed jobs. Among the exposed workers, $44 \%$ of the cohort had cumulative exposures which were between 0.01 and 0.5 ppm-years, $34 \%$ had exposures of $0.51-5.5$ ppm-years, and $14 \%$ had cumulative exposures which exceeded $5.5 \mathrm{ppm}$ years. Alcohols, melamine, urea, antioxidants, ammonia, plasticizers, dyes and pigments, asbestos, phenol, carbon black, wood dust, stearates, amides, and acetone were other chemicals to which large numbers of workers were exposed.

Bertazzi et al (30) studied a urea and melamine resin plant. The jobs identified were classified as exposed to formaldehyde, exposed to other chemicals, or not exposed. Between 1974 and 1979, the mean levels of formaldehyde (based on 187 measurements) were between 0.2 and $3.8 \mathrm{ppm}$, with individual results as high as $9.8 \mathrm{ppm}$. Other operations in the plant included a styrene resin and an epoxy resin (with possible epichlorohydrin exposure) operation in which exposures may have occurred to xylene, toluene, and methyl isobutyl ketone. No specific identification of other chemicals in the resin operation was made, but we as- sume them to be similar to those in the resin plants studied in the United States (25) and Great Britain (23).

Partanen et al (31) identified 19 sawmills and manufacturers of plywood and formaldehyde glue for a nested case-referent study of respiratory cancer. Exposure assessments by job were based on interviews of cases and referents (or their next-of-kin), available monitoring data, plant visits, and interviews with supervisors and long-term workers to obtain data on ventilation controls, work practices, and other relevant factors. Monitoring was conducted in four companies with few air sampling measurements. Jobs were assigned to one of four exposure categories $(<0.1$, $0.1-<1.0,1.0-<2.0$, and $\geq 2.0 \mathrm{ppm}$ ). The investigations identified $74 \%$ of the cases and referents as exposed to formaldehyde of $<0.1 \mathrm{ppm}, 17 \%$ as exposed to $0.3 \mathrm{ppm}, 7 \%$ as exposed to $1.5 \mathrm{ppm}$, and $2 \%$ as exposed to $3.0 \mathrm{ppm}$. Peaks of $>2 \mathrm{ppm}$ were also noted. Other exposures noted included wood dust, chlorophenols, pesticides, terpenes, phenol, caseinalbumin glues, melamine glues, solvents, exhaust gases, molds, bacteria, and possibly bis(chloromethyl)ether (32).

Stayner et al identified study subjects from the company insurance fund records of three garment manufacturing firms for a PMR study (33) and from company records for an SMR study (34) (two of these plants were also in the PMR study). In the PMR study, recent measurements in two of the plants indicated that air levels ranged from 0.1 to $1.0 \mathrm{ppm}$. Levels were presumably higher in the past. No other chemical exposures were believed to be present. In the SMR study (34) the current geometric mean level of formaldehyde was low, ranging from 0.14 to $0.17 \mathrm{ppm}$ (in 557 samples). Although historical exposure levels to formaldehyde were not available, they were assumed to be substantially higher. The authors stated it was unlikely that substantial peaks or intermittent exposures occurred or that there were other potential chemical confounders.

In other industry-based studies, exposure evaluations have been less detailed. Approaches have included analyses by length of employment $(35,36)$, ever or never exposed $(35,37)$, and physical state of the formaldehyde (liquid or powder) (35).

\section{Case-referent studies}

In the case-referent study by Gerin et al $(38,39)$ information obtained in an interview of the subjects consisted of a detailed occupational history including raw materials and final products, type of workroom, activities of other nearby workers, and presence of gaseous fumes or dusts. A team of hygienists and chemists translated this information into potential exposures (38). For formaldehyde, the authors indicated that the categories of low, medium, and high corresponded roughly to $<0.1,0.1-1.0$, and $>1.0 \mathrm{ppm}$. Among the 4249 subjects interviewed, $760(18 \%)$ were 
judged to have low exposures, 203 moderate exposures $(5 \%)$, and $8(0.2 \%)$ high exposures.

Fayerweather et al (40) supplemented the work history information from the personnel records of seven DuPont plants with information in the medical records and from interviews with co-workers. Available monitoring results were used in the estimation of levels for "continuous" exposure. When monitoring data were nonexistent, interviews of long-term employees were made with regard to sensory perceptions and process descriptions and control changes. The following three levels of "continuous" exposure were identified: $<0.1,0.1-2.0$, and $\geq 2.0 \mathrm{ppm}$. Intermittently exposed jobs were classified as low (peaks $<2 \mathrm{ppm}$ ) or high ( $>2 \mathrm{ppm}$ ) exposure. Other chemicals which were used included asbestos, benzene, carbon tetrachloride, zinc chromate, and acrylonitrile.

In most of the other case-referent studies industrial hygienists classified the jobs held by subjects into semiquantitative categories $(41,42)$ or nominal categories (43-45). Estimates of possible level of exposure were not made. In many cases the subjects were exposed to other chemicals, including known or potential carcinogens (41-45). One study had two industrial hygienists independently evaluate exposure, and risks of nasal cancer were calculated on the basis of each assessment (42).

In summary, several facets regarding the exposure assessments used in these studies are worth noting. The studies of professionals and the case-referent investigations suffer from typical limitations in that exposure is based entirely on job title without detailed information on the facility. Absence of information on levels of exposure in these investigations prevented evaluation of dose-response relationships. Moreover, in most of the studies of professions, other exposures were ignored. Among case-referent studies, those by Gerin et al (39) and Fayerweather et al (40) are stronger because they assembled more information regarding exposures and developed estimates of exposure levels. The exposure assessments in the cohort studies of industrial workers are generally better because actual site visits to the plants under study were made by industrial hygienists. In addition monitoring data were often available. With these data, quantitative estimates were developed and used in exposure-response analyses. Only two of the industrial studies included information on exposure other than formaldehyde $(24,31)$.

\section{Summary of epidemiologic results}

Tables 3 and 4 display results from the epidemiologic studies. To provide a comprehensive review, cancers that were excessive in two or more studies or showed some exposure-response pattern are included in the tabulations (11 sites). The observed and expected numbers presented are generally for exposed persons only. For some studies, the expected numbers were not provided but could be calculated from the data in the paper. The expected numbers from case-referent studies were obtained by dividing the number of exposed cases by the odds ratio.

The observed and expected numbers were summed for studies of professional and industrial groups separately to create combined relative risk (CRR) estimates. This summation approach weights the risk estimates by study size. We also present the proportion of the studies having relative risks greater than 1.0, an approach which weights the contribution from each study equally. The statistical significance of the CRR estimates was assessed according to Bailar \& Ederer (46).

The studies of industrial workers from the United States were not entirely independent, but total overlapping of the study populations did not occur because criteria for entry into the cohorts varied from study to study. In addition, the detail to which exposure to formaldehyde was estimated also varied among the overlapping studies. Studies by Marsh (35) and Liebling et al (37) were on a plant that was also included in the study by Blair et al (25). The plants studied by Wong (36) and Fayerweather et al (40) also included some workers that were studied by Blair et al (25). Two plants were included in both studies by Stayner (33, $34)$. In the summation of the observed and expected numbers, however, results from the earlier study by Stayner (33) and the studies by Marsh (35), Fayerweather et al (40), Wong (36), and Liebling et al (37) were not included because they were generally covered in the later study by Stayner et al (34) or in the study by Blair et al (25). Thus there is no double counting of cancer deaths in the summary statistics provided in this report.

Among professionals (tables 3 and 4), significant excesses occurred for leukemia (CRR 1.6) (11 of the 13 investigations showing excesses ranging from 1.1 to 3.1 ), brain cancer (CRR 1.5) (six of nine studies showing excesses ranging from 1.2 to 3.3 ), and colon cancer (CRR 1.3) (excesses in seven of nine studies ranging from 1.1 to 2.3). Fewer deaths from lung cancer occurred among the professionals than expected (CRR $0.9)$, nine of 15 studies showing a deficit. Overall, mortality from lung cancer among embalmers and funeral directors was about as expected (CRR 1.0), in contrast to the striking deficit among anatomists and pathologists (CRR 0.3). Only one death from nasal cancer occurred among the professionals, less than one death being expected. Observed and expected numbers were presented for nasopharyngeal cancer in only one report, and excesses were observed among black and white men (CRR 2.2). There was an overall deficit for Hodgkin's disease (CRR 0.5) (based on six deaths). Mortality from prostate cancer and for cancer of the buccal cavity and pharynx was about as expected (CRR 1.0).

In contrast to professionals, industrial workers did not show elevated mortality from leukemia (CRR 1.1) 
Table 3. Mortality from cancers of the buccal cavity and pharynx, nasopharynx, lung, nose, prostate, and bladder among persons exposed to formaldehyde. ${ }^{a}(\mathrm{O}=$ observed number of cases, $\mathrm{E}=$ expected number of cases, $\mathrm{RR}=$ relative risk)

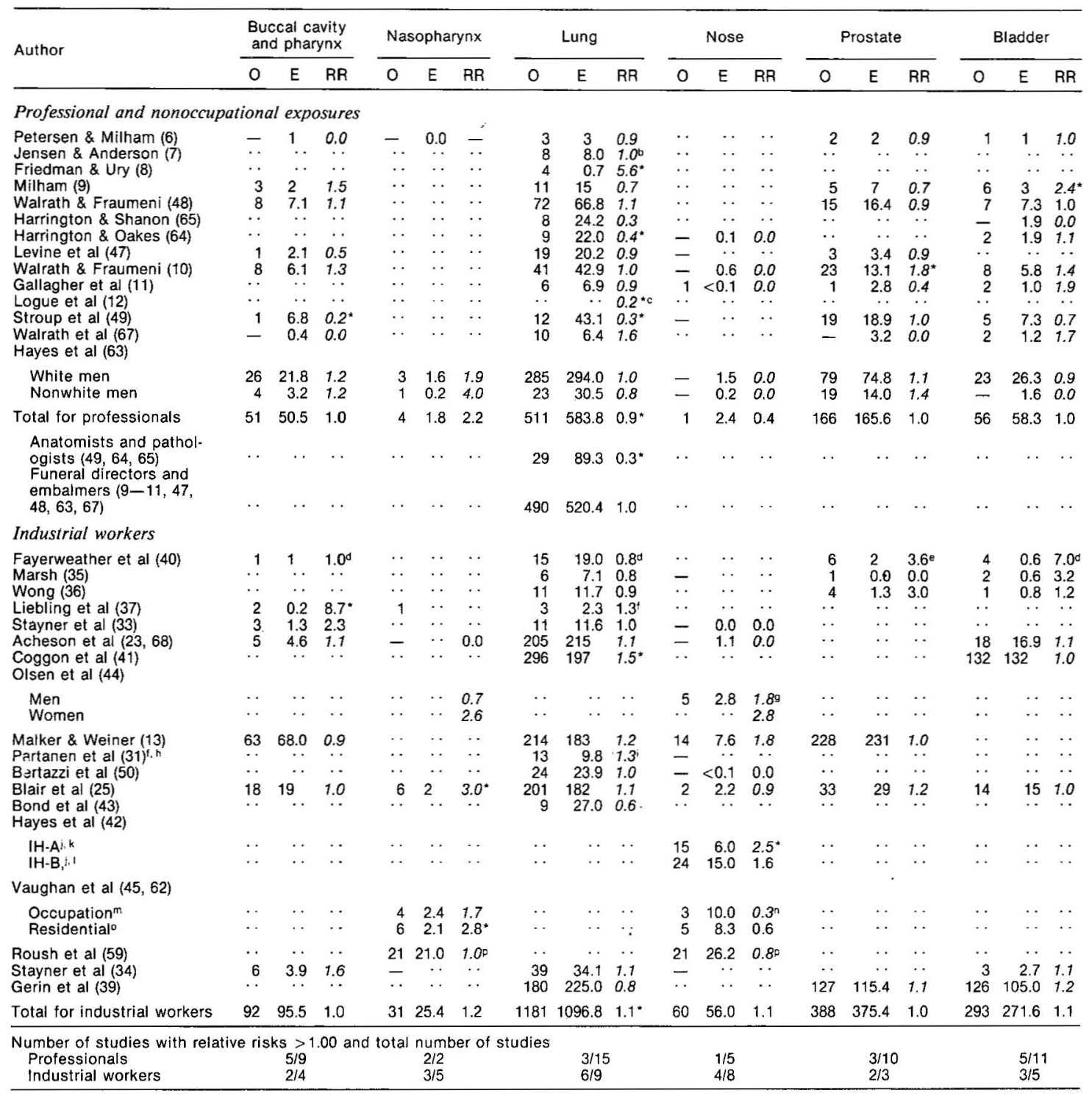

a Data in italics are included in the summary statistics.

b Exposed were those ever employed in pathology, forensic medicine, or anatomy.

d Unexposed versus exposed for $\geq 5$ years with a 20 -year latency.

e Intermittent exposure with $>15$ years of latency.

1 Respiratory cancer and related cancers.

9 Without exposure to wood dusts.

h Lung cancers were 54 of 60 cases.

i Adjusted for cigarette smoking.

i With little or no exposure to wood dusts.

k Exposures estimated by industrial hygienist $A(I \mathrm{H}-\mathrm{A})$.

- Exposures estimated by industrial hygienist $B(\mathrm{IH} \cdot \mathrm{B})$.

m Occupational exposure.

${ }^{n}$ Medium and high exposure strata combined.

- Residential exposure.

D Probably exposed to some level for most of worklife.

* $\mathrm{P}<0.05$.

or brain cancer (CRR 0.9) (tables 3 and 4). A small, but significant, excess of lung cancer was seen among the industrial workers (CRR 1.1), six of nine studies showing excesses. A nonsignificant excess was observed for nasopharyngeal cancer (CRR 1.2), three of five studies showing excesses, nasal cavity cancer (CRR 1.1), four of eight studies showing excesses, and bladder cancer (CRR 1.1), three of five studies showing excesses. Mortality was about as expected from cancers of the buccal cavity and pharynx (CRR 1.0) and pros- 
Table 4. Mortality from cancers of the brain, colon and skin, leukemia, and Hodgkin's disease among persons exposed to formaldehyde. ${ }^{a}(O=$ observed number of cases, $E=$ expected number of cases, $R R=$ relative risk)

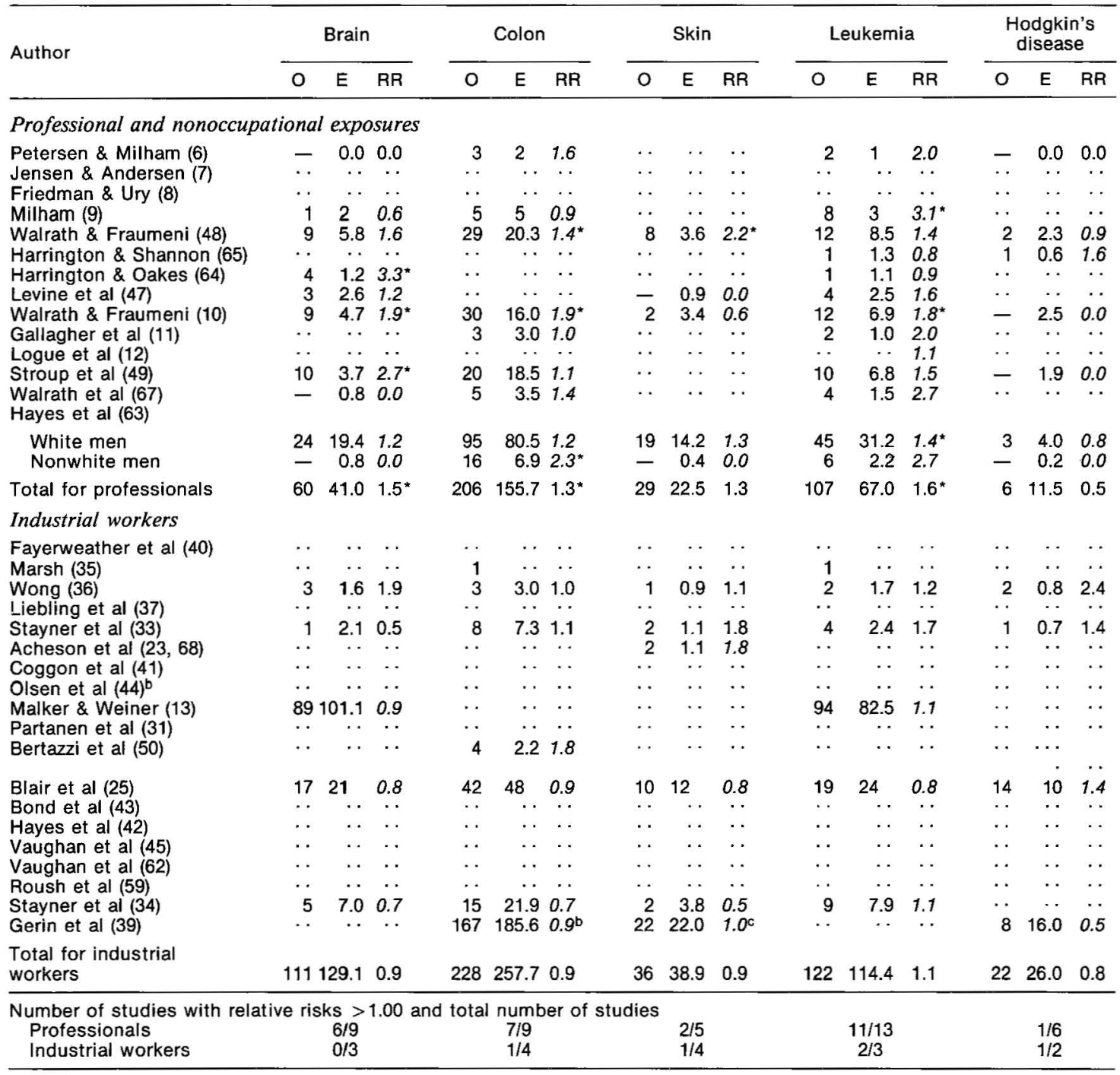

a Data in italics are included in the summary statistics.

b Colon and rectal cancer.

c Melanoma.

$\star \mathrm{P}<0.05$.

tate (CRR 1.0). Overall, fewer deaths occurred than expected for Hodgkin's disease (CRR 0.8) and for cancers of the colon (CRR 0.9) and skin (CRR 0.9).

The risk of nasal cancer was evaluated by exposure level or duration of exposure to formaldehyde (table 5). When the observed and expected numbers from the various studies were combined, no exposure-response gradient was evident from the CRR values. Of the four studies with sufficient information for an exposure-response evaluation, only one had a positive trend (42). On the other hand, for nasopharyngeal cancer, the CRR values rose to 2.1 in the high-exposure category (table 6), a trend which was statistically significant $(X=2.02)$. All three of the studies with exposure-response data showed a rising risk of nasopharyngeal cancer with increasing exposure.

The relative risks for lung cancer by time since first exposure (latency) is shown in table 7. Only three studies of professionals had information on latency. The CRR values for lung cancer in the shorter and longer latency categories for these studies combined were 0.6 and 0.9 , respectively. Risk did not vary for the embalmers by length of time since first exposure $(47,48)$, but it did for the anatomists (49). Among the industrial workers, the CRR was 1.1 for lung cancer for the shorter latency group and $\mathbf{1 . 2}$ for the longer latency group. Three studies showed higher lung cancer risks with longer latency $(23,25,31)$, and three 
Table 5. Relative risks for nasal cancer by level or duration of exposure to formaldehyde. $(0=$ observed number of cases, $\mathrm{E}=$ expected number of cases, $\mathrm{RR}=$ relative risk)

\begin{tabular}{|c|c|c|c|c|c|c|c|c|c|c|}
\hline \multirow{2}{*}{ Author } & \multicolumn{3}{|c|}{ Unexposed } & \multicolumn{3}{|c|}{ Lower level/duration } & \multicolumn{3}{|c|}{ Higher level/duration } & \multirow{2}{*}{$\begin{array}{c}\text { Author's } \\
X \text { for } \\
\text { trend }\end{array}$} \\
\hline & 0 & $E$ & RR & 0 & $E$ & RR & 0 & $E$ & RR & \\
\hline $\begin{array}{l}\text { Blair et al }(25)^{\mathrm{a}} \\
\text { Roush et al }(59)^{\mathrm{b}} \\
\text { Hayes et al }(42)^{\mathrm{c}, \mathrm{d}} \\
\text { Hayes et al }(42)^{\mathrm{c}, \mathrm{e}} \\
\text { Vaughan et al }(45)^{\dagger}\end{array}$ & $\begin{array}{r}\overline{148} \\
48 \\
39 \\
41\end{array}$ & $\begin{array}{l}0.2 \\
148 \\
48 \\
39 \\
41\end{array}$ & $\begin{array}{l}0.0 \\
1.0 \\
1.0 \\
1.0 \\
1.0\end{array}$ & $\begin{array}{r}1 \\
21 \\
8 \\
7 \\
9\end{array}$ & $\begin{array}{c}2 \\
26.2 \\
3.6 \\
7 \\
11.2\end{array}$ & $\begin{array}{l}0.5 \\
0.8 \\
2.2 \\
1.0 \\
0.8\end{array}$ & $\begin{array}{r}1 \\
9 \\
7 \\
17 \\
3\end{array}$ & $\begin{array}{r}1 \\
9.0 \\
2.3 \\
8.1 \\
10.0\end{array}$ & $\begin{array}{l}1.0 \\
1.0 \\
3.0^{*} \\
2.1^{*} \\
0.3\end{array}$ & $\begin{array}{r}0.59 \\
-0.55 \\
3.7^{*} \\
2.41^{*} \\
-2.09^{*}\end{array}$ \\
\hline Total 9 & 228 & 228.2 & 1.0 & 38 & 46.4 & 0.8 & 30 & 28.1 & 1.1 & . \\
\hline
\end{tabular}

a Lower level $=>0-5.5$ ppm-years, high level $=\geq 5.5$ ppm-years.

b Lower level = all exposed, higher level = probably exposed to high levels for at least one year.

c On a scale of $1-9$, lower level $=1-2$ and higher level $=\geq 3$ (all among those exposed to lower levels of wood dusts).

d Exposure estimates from industrial hygienist $A$.

e Exposure estimates from industrial hygienist $B$.

' Lower level versus medium to high levels

$g$ Using data from industrial hygienist $B$ for Hayes et al (42).

* $P \leq 0.05$

Table 6. Relative risks for nasopharyngeal cancer by level or duration of exposure to formaldehyde. $(0=$ observed number of cases, $\mathrm{E}=$ expected number of cases, $\mathrm{RR}=$ relative risk)

\begin{tabular}{|c|c|c|c|c|c|c|c|c|c|c|}
\hline \multirow{2}{*}{ Author } & \multicolumn{3}{|c|}{ Unexposed } & \multicolumn{3}{|c|}{ Lower level/duration } & \multicolumn{3}{|c|}{ Higher level/duration } & \multirow{2}{*}{$\begin{array}{l}\mathrm{X} \text { for } \\
\text { trend }\end{array}$} \\
\hline & 0 & $\mathrm{E}$ & RR & 0 & $E$ & $\mathrm{RR}$ & o & $\mathrm{E}$ & RR & \\
\hline $\begin{array}{l}\text { Blair et al }(28)^{\mathrm{a}} \\
\text { Roush et al }(59)^{\mathrm{b}} \\
\text { Vaughan et al }(45)^{\mathrm{c}}\end{array}$ & $\begin{array}{r}1 \\
126 \\
16\end{array}$ & $\begin{array}{l}0.5 \\
126 \\
16\end{array}$ & $\begin{array}{l}2.0 \\
1.0 \\
1.0\end{array}$ & $\begin{array}{r}2 \\
21 \\
7\end{array}$ & $\begin{array}{c}0.5 \\
21 \\
5.8\end{array}$ & $\begin{array}{l}4.0 \\
1.0 \\
1.2\end{array}$ & $\begin{array}{l}2 \\
7 \\
4\end{array}$ & $\begin{array}{l}0.3 \\
3.1 \\
2.9\end{array}$ & $\begin{array}{l}7.5 \\
2.3^{*} \\
1.4\end{array}$ & $\begin{array}{l}0.83 \\
1.29 \\
0.65\end{array}$ \\
\hline Total & 143 & 142.5 & 1.0 & 30 & 27.3 & 1.1 & 13 & 6.3 & $2.1^{*}$ & $2.02^{*}$ \\
\hline
\end{tabular}

a Unexposed $=<0.5$ ppm-years, lower level $=0.05-<5.5$ ppm-years, higher level $=\geq 5.5$ ppm-years (all among those also exposed to particulates).

b Lower level = probably exposed, higher levels = probably exposed to some higher levels $\geq 20$ years before death .

c Relative exposure scale, low $=$ low, high $=$ medium and high.

* $\mathrm{P} \leq 0.05$.

Table 7. Relative risk (RR) for lung cancer by time since first exposure/employment. $(\mathrm{O}=$ observed number of cases, $\mathrm{E}=\mathrm{ex}$ pected number of cases)

\begin{tabular}{|c|c|c|c|c|c|c|}
\hline \multirow{2}{*}{ Author } & \multicolumn{3}{|c|}{ Shorter latency } & \multicolumn{3}{|c|}{ Longer latency } \\
\hline & 0 & $E$ & RR & 0 & $E$ & $\mathrm{RR}$ \\
\hline \multicolumn{7}{|l|}{ Professionals } \\
\hline $\begin{array}{l}\text { Walrath \& Fraumeni }(48)^{\mathrm{a}} \\
\text { Levine et al }(47)^{\mathrm{b}} \\
\text { Stroup et al }(49)^{\mathrm{c}}\end{array}$ & $\begin{array}{r}39 \\
19 \\
4\end{array}$ & $\begin{array}{l}36.1 \\
20.9 \\
40.0\end{array}$ & $\begin{array}{l}1.1 \\
0.9 \\
0.1\end{array}$ & $\begin{array}{r}35 \\
18 \\
8\end{array}$ & $\begin{array}{l}34.7 \\
18.6 \\
12.2\end{array}$ & $\begin{array}{l}1.0 \\
1.0 \\
0.6\end{array}$ \\
\hline Total for professionals & 62 & 97.0 & 0.6 & 61 & 65.5 & 0.9 \\
\hline \multicolumn{7}{|l|}{ Industrial workers } \\
\hline $\begin{array}{l}\text { Acheson et al }(23)^{d} \\
\text { Blair et al }(25)^{\mathrm{e}} \\
\text { Stayner et al }(34)^{\mathrm{e}} \\
\text { Bond et al }(43)^{\dagger} \\
\text { Bertazzi et al }(50)^{\mathrm{g}} \\
\text { Partanen et al }(31)^{\dagger}\end{array}$ & $\begin{array}{r}80 \\
68 \\
31 \\
9 \\
14 \\
13\end{array}$ & $\begin{array}{l}70.0 \\
69 \\
25.1 \\
14.5 \\
7.3 \\
9.8\end{array}$ & $\begin{array}{l}1.1 \\
1.0 \\
1.2 \\
0.6 \\
1.9^{\star} \\
1.3^{h}\end{array}$ & $\begin{array}{r}26 \\
151 \\
8 \\
4 \\
10 \\
8\end{array}$ & $\begin{array}{c}19.6 \\
114 \\
9.2 \\
16.7 \\
15.3 \\
5.0\end{array}$ & $\begin{array}{l}1.3 \\
1.3^{*} \\
0.9 \\
0.3 \\
0.6^{h} \\
1.6^{h}\end{array}$ \\
\hline Total for industrial workers & 215 & 195.7 & 1.1 & 207 & 179.8 & 1.2 \\
\hline
\end{tabular}

a Shorter latency $=<35$ years; longer latency $=\geq 35$ years.

b Shorter latency $=\leq 10$ years; longer latency $=\geq 20$ years.

Joined association: shorter latency = before 1930; longer latency = after 1930.

d Entered work force: shorter latency = before 1946; longer latency = after 1946.

Shorter latency $=<20$ years; longer latency $=\geq 20$ years.

i Shorter latency $=$ total group; longer latency $=\geq 10$ years.

9 Shorter latency $=\leq 15$ years; longer latency $=\geq 15$ years.

Adjusted for cigarette smoking.

$P \leq 0.05$. showed higher risks with shorter latency $(34,43,50)$. Risk of lung cancer by level or duration of exposure to formaldehyde is shown in table 8. Among the professionals, fewer deaths from lung cancer occurred than expected in both categories, and the relative risk was lower in the higher exposure category (CRR 0.7) than in the lower exposure category (CRR 1.0). In the studies of industrial workers there was a small, but statistically significant, excess of lung cancer among workers with shorter duration or lower levels of exposure (CRR 1.2), but not among the longer or more heavily exposed (CRR 1.0) workers. Using duration as the only measure of exposure resulted in a CRR of 1.3 for the shorter duration category and 0.8 for the longer one. The CRR values for the low and high categories based on level of exposure were identical (1.1 and 1.1, respectively), however. Neither the individual studies nor the summary statistics showed significant trends between level of formaldehyde exposure and risk of lung cancer. 
Table 8. Lung cancer by level or duration of exposure to formaldehyde. $(\mathrm{O}=$ observed number of cases, $E=$ expected number of cases, $\mathrm{RR}=$ relative risk, $\cdot=$ not applicable, only two categories with estimates)

\begin{tabular}{|c|c|c|c|c|c|c|c|c|c|c|}
\hline \multirow{2}{*}{ Author } & \multicolumn{3}{|c|}{ Unexposed } & \multicolumn{3}{|c|}{ Lower level/duration } & \multicolumn{3}{|c|}{ Higher level/duration } & \multirow{2}{*}{$\begin{array}{l}X \text { for } \\
\text { trend }\end{array}$} \\
\hline & 0 & $E$ & $\mathrm{RR}$ & 0 & $E$ & RR & 0 & $E$ & RR & \\
\hline \multicolumn{11}{|l|}{ Professionals } \\
\hline $\begin{array}{l}\text { Walrath \& Fraumeni }(10)^{\mathrm{a}} \\
\text { Walrath \& Fraumeni }(48)^{\mathrm{b}, \mathrm{c}} \\
\text { Stroup et al }(49)^{\mathrm{d}}\end{array}$ & $\begin{array}{l}\cdots \\
\cdots \\
\cdots\end{array}$ & $\begin{array}{l}\cdots \\
\cdots \\
\cdots\end{array}$ & $\begin{array}{l}\cdots \\
\cdots \\
\cdots\end{array}$ & $\begin{array}{r}17 \\
47 \\
6\end{array}$ & $\begin{array}{l}16.0 \\
42.1 \\
15.0\end{array}$ & $\begin{array}{l}1.1 \\
1.1 \\
0.4\end{array}$ & $\begin{array}{r}24 \\
27 \\
6\end{array}$ & $\begin{array}{l}27.0 \\
28.6 \\
26.7\end{array}$ & $\begin{array}{l}0.9 \\
0.9 \\
0.2\end{array}$ & : \\
\hline Total for professionals & . & . & $\cdots$ & 70 & 73.1 & 1.0 & 57 & 82.3 & $0.7^{*}$ & . \\
\hline \multicolumn{11}{|l|}{ Industrial workers } \\
\hline $\begin{array}{l}\text { Acheson et al }(23)^{\mathrm{e}} \\
\text { Coggon et al }(41)^{f^{\prime}} \\
\text { Blair et al }(24)^{\mathrm{g}} \\
\text { Stayner et al }(34)^{\mathrm{h}} \\
\text { Bertazzi et al }(50)^{\mathrm{i}} \\
\text { Partanen et al }(31)^{\mathrm{c}, \mathrm{j}} \\
\text { Gerin et al }(39)^{\mathrm{k}}\end{array}$ & $\begin{array}{l}37 \\
\because \\
14 \\
\because \\
\because \\
47 \\
\cdots\end{array}$ & $\begin{array}{r}43 \\
21 \\
\cdots \\
\cdots \\
47.0 \\
\cdots\end{array}$ & $\begin{array}{c}0.9 \\
\ddot{0} \\
0.7 \\
\cdots \\
\cdots \\
1.0 \\
\cdots\end{array}$ & $\begin{array}{r}39 \\
296 \\
88 \\
29 \\
19 \\
10 \\
33\end{array}$ & $\begin{array}{c}42 \\
197.3 \\
72 \\
21.6 \\
16.5 \\
6.6 \\
66.0\end{array}$ & $\begin{array}{l}0.9 \\
1.5^{*} \\
1.2 \\
1.3 \\
1.2 \\
1.5 \\
0.5\end{array}$ & $\begin{array}{r}109 \\
44 \\
62 \\
10 \\
5 \\
3 \\
24\end{array}$ & $\begin{array}{l}97 \\
48.9 \\
56 \\
12.5 \\
7.4 \\
2.2 \\
16.0\end{array}$ & $\begin{array}{l}1.1 \\
0.9 \\
1.1 \\
0.8 \\
0.7 \\
1.4 \\
1.5\end{array}$ & $\begin{array}{c}1.45 \\
\cdot .10 \\
\cdot \\
1.09 \\
\cdot\end{array}$ \\
\hline Total for industrial workers & 98 & 111.0 & 0.9 & 514 & 422.0 & $1.2^{*}$ & 250 & 240.0 & 1.0 & 0.20 \\
\hline $\begin{array}{l}\text { Cohort studies only } \\
(23,24,31,34,50) \\
\text { With estimates of level } \\
(23,24,31) \\
\text { With duration only }(34,50)\end{array}$ & $\begin{array}{l}98 \\
98 \\
\cdots\end{array}$ & $\begin{array}{l}111.0 \\
111.0\end{array}$ & $\begin{array}{l}0.9 \\
0.9\end{array}$ & $\begin{array}{r}185 \\
137 \\
48\end{array}$ & $\begin{array}{r}158.7 \\
120.0 \\
38.1\end{array}$ & $\begin{array}{l}1.2^{*} \\
1.1 \\
1.3\end{array}$ & $\begin{array}{r}189 \\
174 \\
15\end{array}$ & $\begin{array}{r}185.1 \\
155.2 \\
19.9\end{array}$ & $\begin{array}{l}1.0 \\
1.1 \\
0.8\end{array}$ & $\begin{array}{l}0.75 \\
1.75\end{array}$ \\
\hline
\end{tabular}

a Lower $=<20$ years of licensure; higher $=\geq 20$ years of licensure.

b Embalmers and funeral directors; embalmers only.

c Respiratory cancer.

d Lower $=<20$ years of membership; higher $=\geq 20$ years of membership.

Lower $=0.1-0.5 \mathrm{ppm}$; higher $=>2.0 \mathrm{ppm}$.

$f$ Lower = all exposed; higher $=$ high exposure.

g Lower $=>0-<0.5$ ppm-years; higher $=\geq 5.5$ ppm-years

h Lower $=>3$ months $-<3$ years in duration; higher $=\geq 10$ years in duration,

Lower $=<10$ years of exposure; higher $=\geq 10$ years of exposure.

i Lower $=0.1-1 \mathrm{ppm}$; higher $=\geq 1 \mathrm{ppm}$.

$k$ Lower level $=\geq 10$ years of exposure at low levels; higher level $=\geq 10$ years of exposure at high levels.

* $\mathrm{P} \leq 0.05$.

\section{Discussion}

As noted in earlier reviews, professional and industrial workers exposed to formaldehyde have exhibited different cancer patterns $(4,5,22,51)$. The excesses for leukemia and cancers of the colon and brain observed among professionals were not seen among industrial workers. The excesses were rather consistent for leukemia (11 of 13 studies), brain cancer (six of nine studies), and colon cancer (seven of nine studies) among professionals. Studies lacking such excesses had few reported deaths (generally less than three). Diagnostic bias (52) may be a concern for these cancers, since professionals may receive better medical care than the general population which served as the reference in the investigations. Among anatomists (49), however, the relative risks for leukemia and brain cancer remained elevated when mortality rates from psychiatrists were used to generate the expected numbers, a finding suggesting that the excess risks for anatomists cannot be entirely explained by diagnostic bias or general socioeconomic bias. In the study of anatomists (49) the SMR decreased but remained elevated when expected deaths from benign tumors of the nervous system (conditions likely to be misdiagnosed) were included in the estimate of expected brain cancers, again a finding suggesting that the excess is unlikely to be entirely due to diagnostic bias.

Industrial workers appear to have TWA values of formaldehyde similar to those of professional workers. The lack of excesses of leukemia or cancer of the brain or colon among industrial workers would seem to indicate that formaldehyde is not contributing to the excesses of these tumors. Experimental investigations also suggest that formaldehyde is unlikely to induce cancer in tissues other than those in which direct contact can occur. The formaldehyde concentration was not increased in the blood of rats exposed to 14.4 ppm (53), and $\left({ }^{14} \mathrm{C}\right)$ - and $\left({ }^{3} \mathrm{H}\right)$-formaldehyde was not found in the bone marrow in labeling experiments (54). Professionals may, however, experience higher peak exposures on a more frequent basis than industrial workers. This possibility may be important if, during high peak exposures, body defenses are overwhelmed (55). In balance, these data suggest that the excesses for leukemia and brain cancer among professionals cannot be entirely explained by socioeconomic confounding or diagnostic bias, but the factors in the work environment responsible for these excesses have not been identified. Pathologists, anatomists, and embalmers differ from industrial workers in that they may be exposed to other substances used in the preserva- 
tion of tissues, including dyes and stains, glycol, and xylene, as well as biologic materials (14-21). Additional investigations are needed to determine if these exposures alone or in combination with formaldehyde contribute to the cancer excesses noted among professionals.

Among industrial workers, cancers of the respiratory system have received the most attention. A small, but statistically significant, excess occurred for cancer of the lung (CRR 1.1), and an overall exposureresponse gradient occurred for cancer of the nasopharynx. There was a small overall nonsignificant excess for nasal cancer (CRR 1.1), but the risk of this cancer did not increase with increasing duration or level of exposure. Several lines of evidence suggest, however, that formaldehyde may be involved in the development of this cancer in humans. First, two casereferent studies noted excess risks among persons exposed to formaldehyde $(42,44)$. The occurrence of an exposure-response gradient from the two independent assessments of exposure in the study from The Netherlands (42) is of particular interest. Exposure assessment is especially difficult in case-referent studies. Random exposure misclassification is to be expected, but it would tend to dilute exposure-response patterns. Similar estimates of risk from independent assessments of exposure increases one's confidence in the findings. Second, in the investigation from The Netherlands (42), squamous cell cancer was the histological type of nasal cancer most strongly associated with formaldehyde, and this was the type of cancer seen among rodents exposed to formaldehyde $(1,2)$. The Danish case-referent study, however, did not find that exposure to formaldehyde was particularly associated with squamous cell cancer of the nose (56). Third, hyperplasia and squamous cell metaplasia of the nasal mucosa, reported among woodworkers (57) and chemical workers exposed to formaldehyde (58), correspond to lesions observed among rodents in bioassays $(1,2)$ and lend biologic credibility to the hypothesis that formaldehyde is a risk factor for nasal cancer in humans. Potential confounding by other occupational factors remains a problem, however.

In the case-referent studies for nasal cancer $(42,44$, 59) many workers exposed to formaldehyde may have also had exposure to wood dust, a recognized nasal carcinogen, and it is unclear whether its potential effects were entirely removed. In studies in Denmark (44) and The Netherlands (42), however, elevated risks occurred among persons who held jobs for which exposure to wood dusts was less likely. Other casereferent studies in the United States (60) and Nordic countries (61) found no association between formaldehyde exposure and nasal cancer, but they were not specifically designed to assess risks from this chemical. Several cohort studies of industrial workers or professional workers have also failed to detect excesses of nasal cancer $(23,25,34)$ although the power of the studies was small.
The excesses for cancer of the nasopharynx occurred in a cohort study (relative risk 3.0) and in case-referent studies (CRR 1.2, based on two studies). In the cohort study (28) relative risks for nasopharyngeal cancer increased steadily to 7.5-fold among workers who had cumulative exposure to formaldehyde of $\geq 5.5$ ppm-years and exposure to formaldehyde-containing particulates. No exposure-response relationship was found, however, among persons who were exposed to formaldehyde but not exposed to particulates. In a case-referent study $(45,62)$ in which exposure to formaldehyde was assessed from workplace and residential sources, the relative risks for nasopharyngeal cancer rose from 1.7 for persons with occupational exposure alone, to 2.8 for persons with residential exposures alone, to 6.7 for persons with both occupational and residential exposures $(45,62)$. These relative risks were adjusted for ethnic origin and cigarette smoking. In the other case-referent study (59) the relative risk of nasopharyngeal cancer rose with probable level of exposure to 2.3 for those exposed at higher levels 20 or more years before death. Contradictory results regarding nasopharyngeal cancer were obtained in other studies. No excesses occurred in most studies of professionals and no deaths from cancer of the nasopharynx were reported in the study of chemical workers in Great Britain (23) or in the investigation of garment workers in the United States (34). In these investigations, however, the expected numbers were small. The excess of nasopharyngeal cancer among black and white male embalmers in a recent study from the United States is the first report among professionals and further points to a role for formaldehyde in the origin of this tumor (63). In Denmark, a case-referent study noted an association between formaldehyde exposure and nasopharyngeal cancer among women, but not among men (44). Despite these inconsistencies, biologic plausibility (excesses for a site where direct contact may occur) and the occurrence of exposure-response patterns in studies of different designs (cohort mortality and case-referent) suggest that a causal association between formaldehyde exposure and cancer of the nasopharynx seems credible and likely. As with nasal cancer, small numbers, inconsistency among studies, and a possible independent role for particulates preclude definitively labeling formaldehyde as a nasopharyngeal carcinogen.

The findings regarding lung cancer are difficult to interpret. The significant deficits of lung cancer that occurred among anatomists and pathologists were very likely due to a lower prevalence of smoking among these health professionals $(49,64,65)$ than among the general population (66). Smoking habits among embalmers and funeral directors appear, however, to resemble that of the general population. In a study of United States veterans (67) the proportion of embalmers who ever smoked cigarettes $(57 \%)$ did not differ from that of the entire study population $(58 \%)$. Smoking, therefore, does not appear to confound com- 
parisons between embalmers and the general population. Embalmers, however, do not appear to experience an excess of lung cancer (CRR 1.0). In addition, among funeral directors and embalmers, the risk of lung cancer did not increase with time since first exposure.

Industrial workers had a small excess of lung cancer (CRR 1.1), but the overall relative risks increased little with latency. Neither did the risk of lung cancer increase with duration or level of exposure to formaldehyde among industrial workers, findings resembling those of studies of embalmers and funeral directors. The CRR values decreased with increasing duration of exposure and were similar in the low- and highexposure categories.

In the studies of multiple plants in the United States $(24,25,28,29,33,34)$ and Great Britain $(23,68)$ excess mortality from lung cancer was not observed in all the plants. Among garment workers (34) in the United States, deficits were observed at two plants, whereas one had an excess. In the study of workers at 10 plants producing and using formaldehyde $(24,25)$ an excess of lung cancer occurred among workers with $\geq 20$ years of latency for six plants, and deficits occurred for four plants. The plants with the excesses were not necessarily the plants with the highest levels of exposure. In Great Britain (23) three plants had deficits, and two had excesses. One of the plants with an excess had the highest exposure levels in the study and showed an exposure-response relationship (the SMR rising to 118 for the most heavily exposed). The other plant with an overall excess showed no such exposureresponse relationship and had levels similar to those found in the other plants in the study.

In both the American and British studies of chemical workers (23-25) the lung cancer excess was largely confined to workers involved in the production of resins and molding compounds. In the American study, lung cancer was not elevated among workers exposed to formaldehyde unless they also came into contact with substances associated with the production of resins and molding compounds (24). The study of workers in an Italian resin plant also noted an excess of lung cancer, but it did not appear to be directly related to formaldehyde exposure (50). An update (69) of the Finnish cohort (31) noted an excess of cancer of the upper respiratory tract but not an excess of lung cancer.

Some investigators have speculated that the healthy worker effect may contribute to the lack of an exposure-response gradient for lung cancer $(70,71)$. Robins et al (70), using an analysis which controlled for this problem, concluded that the healthy worker effect was not an explanation for the failure to observe an exposure-response pattern in the Blair et al study (25). Sterling \& Weinkam (71), in another reanalysis of these data, confirmed the excess of lung cancer reported by the original authors (25) but concluded that it was caused by formaldehyde. An error in the counting of deaths resulted in an inclusion of approximate- ly three times as many deaths in the analyses as existed in the cohort (29). In a letter addressing this problem (72) Sterling \& Weinkam reported an excess of lung cancer that rose with level of exposure. In these analyses, however, more deaths from lung cancer occurred than were noted in the original analysis by Blair et al (25). These new analyses (72) may have included contributing causes of death from lung cancer, but contributing causes do not appear to be included in the analyses of all cancers combined.

Based on findings from all the reviewed studies, a causal association between exposure to formaldehyde and lung cancer cannot be entirely discounted, but many of the traditional criteria for causality in epidemiologic investigations are missing. The excess risk was small among industrial workers (CRR 1.1) and was not seen consistently in all the plants studied. In some plants there were deficits. No such excess for lung cancer occurred among the embalmers. Overall, there was a slight increase in the risk of lung cancer with time since first exposure among the industrial workers, but this pattern was also inconsistent by study. Risks increased with latency in two of the three studies of professionals which included information on latency effects, but in only two of the six studies of industrial workers. A causal association was not suggested by the mortality pattern either by level or by duration of exposure. In three studies among professionals, risks were lower for the workers exposed to formaldehyde for longer durations than for those with shorter durations, and in the industry studies the risks were lower among the heavier or longer exposed workers in four of six studies. Furthermore, elevated mortality from lung cancer among workers in certain operations involving resins and molding compounds suggests that further evaluation of exposures in this process in the American, British, and Italian cohorts may help clarify the role of formaldehyde and other substances in the excess of lung cancer seen in some of these studies.

In summary, we conclude that it is likely that the excesses of nasopharyngeal cancer observed were caused by exposure to formaldehyde. The association with nasal cancer is plausible, but somewhat less persuasive than that for nasopharyngeal cancer. The absence of excesses for leukemia and cancers of the colon and brain among industrial workers suggests that the associations seen among professional workers may not be due to formaldehyde. Although a role for formaldehyde in the excess of lung cancer cannot be dismissed, inconsistencies among and within studies of industrial workers suggest that this association is not causal; however, other interpretations are possible. Formaldehyde may be an effective carcinogen only in the presence of other exposures, which were not consistent from study to study, or it may be a weak carcinogen whose effect was easily masked by the presence of lung carcinogens that varied from study to study. 


\section{References}

1. Kerns WD, Pavkov KL, Donofrio DJ, Gralla EJ, Swenberg JA. Carcinogenicity of formaldehyde in rats and mice after long-term inhalation exposure. Cancer Res 1983;43:4382-4392.

2. Sellakumar A, Albert R, Snyder C. Carcinogenicity of formaldehyde and hydrogen chloride in rats. Toxicol Appl Pharmacol 1985;81:401—6.

3. National Institute for Occupational Safety and Health. National occupational hazards survey. Cincinnati, $\mathrm{OH}$ : National Institute for Occupational Safety and Health, 1974. (DHEW publication; no 74-127, 1974.)

4. International Agency for Research on Cancer. Overall evaluation of carcinogenicity: an updating of IARC monographs volumes 1 to 42. Lyon: International Agency for Research on Cancer, 1988. (IARC monographs on the evaluation of carcinogenic risks to humans; suppl 7.)

5. Higginson J, Jensen OM, Kinlen L, et al. Epidemiology of chronic occupational exposure to formaldehyde: report of the AD HOC panel on health aspect of formaldehyde. Toxicol Ind Health 1988;4:77-90.

6. Peterson GR, Milham S. Occupational mortality in the state of California 1959-1961. Cincinnati, OH: National Institute for Occupational and Health, 1980. (DHEW (NIOSH) publ; no 80-104.)

7. Jensen OM, Andersen SK. Lung cancer risk from formaldehyde. Lancet 1982;1:913.

8. Friedman GD, Ury HK. Screening for possible drug carcinogenicity: second report of findings. J Natl Cancer Inst 1983;71:1165-75.

9. Milham S. Occupational mortality in Washington state 1950- 1979. Cincinnati, OH: National Institute for Occupational Safety and Health, 1983. (DHHS (NIOSH) publ; no 83-116.)

10. Walrath J, Fraumeni, JF Jr. Cancer and other causes of death among embalmers. Cancer Res 1984;44:463841.

11. Gallagher RP, Threlfall WJ, Band PR, Spinelli JJ, Coldman AJ. Occupational mortality in British Columbia 1950-1978. Ottawa: Statistics Canada, Health and Welfare Canada, 1986.

12. Logue JM, Burrick MK, Jessup CL. Mortality among radiologists and pathologists in the radiation registry of physicians. J Occup Med 1986;28:91-9.

13. Malker H, Weiner J. Cancer-miljöregistret: exempel på utnyttjande av register - epidemiologi inom arbetsmiljöområdet [Cancer-environment register: example of register use - occupational epidemiology]. Stockholm: Arbetarskyddsverket, 1984: 80-3. (Arbete och hälsa 1984:9.)

14. Laughlin JS, Vacirca SJ, Duplissey JR. Exposure of embalmers and physicians by radioactive cadavers. Health Physics 1968;15:451-5.

15. Williams JM, Levine RJ, Bluden PB. Exposure of embalmers to formaldehyde and other chemicals. Am Ind Hyg Assoc J 1984;45:175-6.

16. Moore LL, Ogrodnik EC. Occupational exposure to formaldehyde in mortuaries. J Environ Health 1986; 49:32-5.

17. Kerfoot EJ, Mooney TF. Formaldehyde and paraformaldehyde study in funeral homes. Am Ind Hyg Assoc J 1975;36:533-7.

18. Clausz JC, MacIntyre BA, Malone ES, Twelmeyer JM. Atmospheric formaldehyde levels in an academic laboratory. J Chem Educ 1984;61:A121-3.

19. Elliott L. Health hazard evaluation report on Tufts Medical School. Cincinnati, OH: National Institute for Occupational Safety and Health, 1980. (HE 79-86$675,1980$.

20. Perkins J, Kimbrough JD. Formaldehyde exposure in a gross anatomy laboratory. J Occup Med 1985;27: $813-5$.
21. Yager $\mathbf{J}$. Exposure to formaldehyde embalming solution in an anatomy laboratory. Presented at the annual meeting of the American Public Health Association in Dallas, TX, December, 1983.

22. Anonymous. Report on the consensus workshop on formaldehyde. Environ Health Perspect 1984;58:32381.

23. Acheson ED, Gardner MJ, Pannett B, Barnes HR, Osmond $C$, Taylor CP. Formaldehyde in the British chemical industry. Lancet 1984;1:611-16.

24. Blair A, Stewart PA, Hoover RN. Mortality from lung cancer among workers employed in the formaldehyde industry. Am J Ind Med 1990:17:683-99.

25. Blair A, Stewart P, O'Berg M, et al. Mortality among industrial workers exposed to formaldehyde. J Natl Cancer Inst 1986;76:1071-84.

26. Stewart PA, Blair A, Cubit DA, et al. Estimating historical exposures to formaldehyde in a retrospective mortality study. Appl Ind Hyg 1986;1:34-41.

27. Stewart $\mathbf{Y A}$, Cubit DA, Blair A. Formaldehyde exposure levels in seven industries. Appl Ind Hyg 1987;2:231-6.

28. Blair A, Stewart PA, Hoover RN, et al. Cancers of the nasopharynx and oropharynx and formaldehyde exposure. J Natl Cancer Inst 1987;78:191-2.

29. Blair A, Stewart PA. Comments on the reanalysis of the National Cancer Institute study of workers exposed to formaldehyde. J Occup Med 1989;31:881.

30. Bertazzi PA, Pesatori AC, Radice L, Zocchetti C, Vai $\mathrm{T}$. Exposure to formaldehyde and cancer mortality in a cohort of workers producing resins. Scand J Work Environ Health 1986;12:461-8.

31. Partanen T, Kauppinen T, Nurminen M, et al. Formaldehyde exposure and respiratory and related cancers: a case-referent study among Finnish woodworkers. Scand J Work Environ Health 1985;11:409-15.

32. Kauppinen TP, Niemela RI. Occupational exposure to chemical agents in the particleboard industry. Scand $\mathbf{J}$ Work Environ Health 1985;11:357-63.

33. Stayner L, Smith AB, Reeve G, Blade L, Elliott L, Keenlyside R, Halperin W. Proportionate mortality study of workers in the garment industry exposed to formaldehyde. Am J Ind Med 1985;7:229—40.

34. Stayner, LT, Elliott L, Blade L, Keenlyside R, Halperin W. A retrospective cohort mortality study of workers exposed to formaldehyde in the garment industry. Am J Ind Med 1988;13:667-81.

35. Marsh GM. Proportional mortality among chemical workers exposed to formaldehyde. In: Gibson JE, ed. Formaldehyde toxicity. New York, NY: Hemisphere Publishing Corporation, 1983:237-55.

36. Wong $\mathrm{O}$. An epidemiologic mortality study of a cohort of chemical workers potentially exposed to formaldehyde with a discussion on SMR and PMR. In: Gibson JE, ed. Formaldehyde toxicity. New York, NY: Hemisphere Publishing Corporation, 1983:256-72.

37. Liebling $T$, Roseman KD, Pastides $H$, Griffin RG, Lemeshow S. Cancer mortality among workers exposed to formaldehyde. Am J Ind Med 1984;5:423-8.

38. Gerin M, Siemiatycki J, Kemper H, Begin D. Obtaining occupational exposure histories in epidemiologic case-control studies. J Occup Med 1985;27:420-6.

39. Gerin M, Siemiatycki J, Nadon L, DeWar R, Krewski D. Cancer risks due to occupational exposure to formaldehyde: results of a multi-site case-control study in Montreal. Int J Cancer 1989;44:53-8.

40. Fayerweather WE, Pell S, Bender JR. Case-control study of cancer deaths in DuPont workers with potential exposure to formaldehyde. In: Clary JJ, Gibson JE, Waritz RS, ed. Formaldehyde: toxicology, epidemiology, mechanisms. New York, NY: Marcel Dekker, Inc, 1983: 47-121.

41. Coggon D, Pannett B, Acheson ED. Use of job-exposure matrix in an occupational analysis of lung and bladder 
cancers on the basis of death certificates. J Natl Cancer Inst 1984;72:61-5.

42. Hayes RB, Raatgever JW, De Bruyn A, Gerin M. Cancer of the nasal cavity and paranasal sinuses and formaldehyde exposure. Int J Cancer 1986;37:487-92.

43. Bond GG, Flores GH, Shellenberger RJ, Cartmill JB, Fishbeck WA, Cook RR. Nested case-control study of lung cancer among chemical workers. Am J Epidemiol 1986;124:53-66.

44. Olsen JH, Jensen SP, Hink M, Faurbo K, Breum NO, Jensen OM. Occupational formaldehyde exposure and increased nasal cancer risk in man. Int J Cancer 1984; 34:639-44.

45. Vaughan TL, Strader C, Davis S, Daling JR. Formaldehyde and cancers of the pharynx, sinus and nasal cavity: I. occupational exposures. Int J Cancer 1986;38: $677-88$

46. Bailar JC, Ederer F. Significance factors for a ratio of a Poisson variable and its expectation. Biometrics 1964; 20:639-43.

47. Levine RJ, Andjelkovich DA, Shaw LK. The mortality of Ontario undertakers and a review of formaldehyderelated mortality studies. J Occup Med 1984;26:740-46.

48. Walrath J, Fraumeni JF Jr. Mortality patterns among embalmers. Int J Cancer 1983;31:407-411.

49. Stroup NE, Blair A, Erikson GE. Brain cancer and other causes of death in anatomists. J Natl Cancer Inst 1986; 77:1217-24.

50. Bertazzi PA, Pesatori A, Guercilena S, Consonni D, Zoccheti C. Rischio cancerogeno per i produttori di resine exporti a formaldeide: extensione del follow-up. Med Lav 1990;80:111-122.

51. Blair A, Walrath J, Malker H. Review of epidemiologic evidence regarding cancer and exposure to formaldehyde. In: Turoski V, ed. Formaldehyde - analytical chemistry and toxicology. Washington, DC: American Chemical Society, 1985:261-73.

52. Greenwald P, Friedlander BR, Lawrence CE. Diagnostic sensitivity bias - an explanation for an apparent brain tumor excess. J Occup Med 1981;23:690-4.

53. Heck H D'A, Casanova-Schmitz M, Dodd PB, Schachter EN, Witek T, Tosun T. Formaldehyde (FA) concentrations in the blood of humans and F-344 rats exposed to FA under controlled conditions. Am Ind Hyg Assoc J 1985; 46:1-3.

54. Casanova-Schmitz M, Starr TB, Heck H D'A. Differentiation between metabolic incorporation and covalent binding in the labelling of macromolecules in the rat nasal mucosa and bone marrow by inhaled $\left({ }^{14} \mathrm{C}\right)$ - and $\left({ }^{3} \mathrm{H}\right)$ formaldehyde. Toxicol Appl Pharmacol 1984;76: $26-44$.

55. Swenberg JA, Barrow CS, Boreiko CJ, et al. Non-linear biologic responses to formaldehyde and their implications for carcinogenic risk assessment. Carcinogenesis 1983;4:945-52.

56. Olsen JH, Asnaes S. Formaldehyde and risk of squamous cell carcinoma of the sinonasal cavities. $\mathrm{Br} \mathrm{J}$ Ind Med 1986;43:769-74.

57. Edling C, Hellquist H, Odkvist L. Occupational ex- posure to formaldehyde and histopathological changes in the nasal mucosa. Br J Ind Med 1988;45:761-5.

58. Boysen M, Zadig E, Digernes V, Apeler V, Reith A. Nasal mucosa in workers exposed to formaldehyde: a pilot study. Br J Ind Med 1990;47:116-21.

59. Roush GC, Walrath J, Stayner LT, Kaplan SA, Flannery JT, Blair A. Nasopharyngeal cancer, sinonasal cancer, and occupations related to formaldehyde: A casecontrol study. J Natl Cancer Inst 1987;79:1221-25.

60. Brinton LA, Blot WJ, Becker JA, et al. A case-control study of cancers of the nasal cavity and paranasal sinuses. Am J Epidemiol 1984;119:896-906.

61. Hernberg S, Collan Y, Degerth R et al. Nasal cancer and occupational exposures. Scand J Work Environ Health 1983;9:208-13.

62. Vaughan TL, Strader C, Davis S, Daling JR. Formaldehyde and cancers of the pharynx, sinus and nasal cavity: Il. residential exposures. Int J Cancer 1986; $38: 685-8$.

63. Hayes RB, Blair A, Stewart PA, Herrick R, Mahar H The mortality of US embalmers and funeral directors. Am $J$ Ind Med (in press).

64. Harrington JM, Oakes D. Mortality study of British pathologists 1974-80. Br J Ind Med 1984;41:188-191.

65. Harrington JM, Shannon HS. Mortality study of pathologists and medical laboratory technicians. Br Med J 1975;4:329-32.

66. Sterling T, Weinkam JJ. Smoking characteristics by type of employment. J Occup Med 1976;18:743-54.

67. Walrath J, Rogot E, Murray J, Blair A. Mortality patterns among US veterans by occupation and smoking status. Bethesda MD: Department of Health and $\mathrm{Hu}-$ man Services, 1985. (NIH Publ; no 85-2756.)

68. Acheson ED, Barnes HR, Gardner MJ, Osmond C, Pannett B, Taylor CP. Formaldehyde process workers and lung cancer. Lancet $1984 ; \mathrm{i}: 1066-7$.

69. Partanen T, Kauppinen T, Hernberg S, et al. Formaldehyde exposure and respiratory cancer in woodworkers - an update. Scand J Work Environ Health 1990;16: 394-400.

70. Robins JM, Pambrum M, Chute C, Blevins D. Estimating the effect of formaldehyde exposure on lung cancer and non-malignant respiratory disease mortality using a method to control for the healthy worker effect. In: Hogstedt C, Reuterwall C, ed. Progress in occupational epidemiology. Amsterdam: Excerpta Medica, 1988: 75-8. (International congress series; no 829.)

71. Sterling T, Weinkam JJ. Reanalysis of lung cancer mortality in a National Cancer Institute study of mortality among industrial workers exposed to formaldehyde. J Occup Med 1988;30:895-901.

72. Sterling T, Weinkam JJ. Reanalysis of lung cancer mortality in a National Cancer Institute study of "Mortality among industrial workers exposed to formaldehyde": additional comments. J Occup Med 1989;31:881--4.

Received for publication: 28 May 1990 